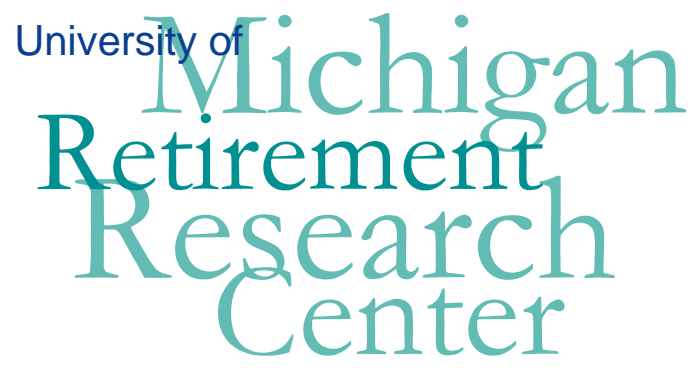

Working Paper

WP 2006-120

\title{
The Role of Conventional Retirement Age in Retirement Decisions
}

Charles Brown

\begin{tabular}{|l|l|l|l|l}
\hline $\mathrm{M}$ & $\mathrm{R}$ & Project \#: UM05-11 \\
\hline $\mathrm{R}$ & $\mathrm{C}$ &
\end{tabular} 


\title{
"The Role of Conventional Retirement Age in Retirement Decisions”
}

\author{
Charles Brown \\ University of Michigan
}

\author{
July 2006 \\ Michigan Retirement Research Center \\ University of Michigan \\ P.O. Box 1248 \\ Ann Arbor, MI 48104 \\ http://www.mrrc.isr.umich.edu/ \\ (734) 615-0422
}

\section{Acknowledgements}

This work was supported by a grant from the Social Security Administration through the Michigan Retirement Research Center (Grant \# 10-P-98358-5). The findings and conclusions expressed are solely those of the author and do not represent the views of the Social Security Administration, any agency of the Federal government, or the Michigan Retirement Research Center.

\section{Regents of the University of Michigan}

David A. Brandon, Ann Arbor; Laurence B. Deitch, Bingham Farms; Olivia P. Maynard, Goodrich; Rebecca McGowan, Ann Arbor; Andrea Fischer Newman, Ann Arbor; Andrew C. Richner, Grosse Pointe Park; S. Martin Taylor, Gross Pointe Farms; Katherine E. White, Ann Arbor; Mary Sue Coleman, ex officio 


\title{
The Role of Conventional Retirement Age in Retirement Decisions
}

\author{
Charles Brown
}

\begin{abstract}
Existing research on retirement behavior tends to ignore "conventional" or "focal" or "usual" retirement ages in the model and estimation, and then ask whether a model which takes no direct account of such conventions can account for the observed spikes in the retirement hazard at age 62 and 65 . This paper, in contrast, focuses on a direct measure of "usual" retirement age, based on a question that has been included in each wave of the Health and Retirement Study HRS).

Using actual survey responses has several advantages: it identifies respondents who say that there is no "usual" retirement age for workers like them; it distinguishes between those who regard 62 and those who regard 65 as the relevant age; and it identifies the not insignificant number of workers for whom the usual age is neither 62 nor 65 . There is little evidence that workers regard 63, the age at which COBRA coverage could provide a bridge to Medicare eligibility, as conventional, or that those affected by the increase in the age of eligibility for "full" retirement benefits under Social Security have adopted 66 or 67 as a focal retirement age.
\end{abstract}

Following Wave I HRS respondents for six additional waves (12 years) so that their actual retirement can be observed shows that the actual retirement hazard is substantially higher at (and around) the age that workers identified in Wave I as the "usual" retirement age for workers like them. This is true even when we control for actual age at each wave, and for baseline values of earnings, wealth, health, and marital status.

The finding that workers are more likely to retire at a particular age if they regard that age as the usual retirement age for workers like them suggests that the direct measures of the usual age may be useful in more formal models of the retirement process. In a world where some workers understand the incentives they face and respond appropriately, but others are poorly informed and overwhelmed by the choices they face, the "usual" retirement age may be a starting point for modeling the behavior of the latter group of workers. 
Formal models of the retirement process treat each individual or household in isolation, forming expectations about the future and then choosing a retirement date that maximizes lifetime utility. Yet recent research on choices made by workers eligible to participate in defined contribution pensions suggests an important role for "default" values in shaping individual choice. One interpretation this finding is that, faced with both uncertainty about the future and difficulties in understanding all of their options, individuals choose the default as a sensible choice for people like them.

One of the more striking and consistent findings in studies of retirement behavior is the increased hazard of retirement at "conventional" retirement ages, especially the "early" and "normal" retirement ages defined by the Social Security program (Hurd, 1990; Peracchi and Welch, 1994). While there is general agreement that workers respond to the incentives provided by Social Security, pensions, and health insurance coverage, there is considerable disagreement whether incentives alone can account for the observed hazard spikes (Gustman and Steinmeier, 1986 and 2002; Rust and Phelan, 1997;

Lumsdaine, Stock, and Wise, 1996). In general, recent structural retirement models have treated "conventional" retirement ages as a residual; they fit the model with no special "effects" at 62 or 65, and ask whether there is an excess hazard at these ages.

Learning whether "conventional" retirement ages have an independent effect on retirement behavior will become more important as public and private (employer) policy interventions change both incentives in ways that may or may not change "conventional" or focal retirement ages. For example, rewarding work past age 65 through the delayed retirement credit changes the incentives while leaving 65 a focal retirement age; changing the age at which one qualifies for "full" Social Security benefits may change both incentives and what is seen as the "conventional" age.

While there is considerable evidence that workers approaching retirement respond to incentives from pensions and Social Security, there is equally convincing evidence that workers are often unable to provide basic information about either their pension or their 
Social Security benefit (Mitchell, 1988; Gustman and Steinmeier, 2001). One possible resolution is that incentives operate very strongly on those respondents who are knowledgeable about their plans (Chan and Stevens, 2003) but that those who are less knowledgeable about retirement planning will be likely to use rules of thumb or accept "default" values for various decisions.

For example, Madrian and Shea (2000) and Choi, Laibson, Madrian, and Metric (2001) find that workers often accept the default option (which they refer to as the "path of least resistance") on $401 \mathrm{~K}$ plan decisions. One interpretation of this behavior is that the default is likely to have been set after some thought by someone paid by the company to design the plan, and so is unlikely to lead to worse choices than active optimization by an uninformed worker. We might then expect that people nearing retirement observe the behavior of slightly older co-workers, and use "average" behavior of this group as an initial guess about what would be optimal for them. If so, we should expect "usual" retirement ages are informative in predicting workers' actual retirement.

The Heath and Retirement Study has, since its inception, asked currently employed workers "what is the usual retirement age for people who work with you or have the same kind of job?" Rather than using 62 and 65 as "focal" choices for all respondents, the HRS data allow one to relate individual workers' reports of "usual" retirement age (URA) in their reference group to these workers' individual retirement decisions. Perhaps surprisingly, little use has been made of responses to the HRS URA question.

Analysis of the usual retirement age question reveals several interesting patterns.

- A significant minority of HRS respondents report that there is no usual retirement age for people like them.

- Among those who do report a URA, one sees a concentration at ages 62 (the earliest age at which Social Security benefits can begin) and at 65 (the "normal" retirement 
age for Social Security and the age of Medicare eligibility), but also considerable dispersion across a much wider range of ages.

- There is no appreciable spike at 63 , the age at which a worker whose firm provides health insurance for workers but not retirees could retire and rely on COBRA coverage until Medicare eligibility.

- There is very little evidence so far that the URA has responded to the increase in the normal retirement age under the Social Security Amendments of 1983.

- Individual who reported a given URA at Wave I (1992) were more likely to retire at or near that age than at other ages. This pattern holds once we control for current age, education, and baseline earnings, health, and marital status. It also holds when we restrict the sample to those who were not covered by a defined benefit pension plan at Wave I, so we are not just seeing the "normal" age being based on spikes in pension accruals at specific ages (Gustman and Steinmeier 1999).

\section{Data}

The Health and Retirement Study began in 1992, interviewing those born in 1931 thru 1941, and their spouses. Original respondents were re-interviewed every two years. In 1998, a new cohort, drawn from those born in 1942-47 was added, and in 2004 those born in 1948-53 were included.

Because our primary interest is in people approaching the retirement decision (rather than on those who are still working past conventional retirement ages, we focus on 1992, 1998, and 2004. In 1992 those born in 1931-41 (i.e., those who would be 51-61 on their birthday that year) were interviewed. In 1998 and 2004, new birth cohorts (1942-47 and 1948-53, respectively) were added.

In each wave of the survey, currently employed workers are asked "what is the usual retirement age for people who work with you or have the same kind of job?" While 
most people respond by giving an age, some respond that there is no "usual" retirement age for people like them. A smaller group responds in terms of years of service rather than years of age (e.g., "after 25 years on the job"). Two other response categories -refuse to answer the question or respond that they don't know - account for a tiny minority of respondents, and they are deleted from all tabulations in this paper.

\section{Usual Retirement Ages by Birth Cohort and Survey Year}

In Table 1, the distribution of usual retirement ages is reported, by birth cohort and year of survey. Looking at the first column, those born in 1931-35, in their 1992 interview, three entries dominate the distribution: nearly 21 percent of this sample reports a usual retirement age of 62 ; a somewhat larger group (31.9\%) choose 65 , and nearly just over 32 percent say there is no "usual" age for workers like them. There are small clusters at round-number ages $(50,55,60$, and 70 - these "round number" values dominate their respective age groups) and at 63 (nearly all of the 63-64 group is at 63), but the basic message of column 1 is that the 13 percent of the sample who report a usual age other than 62 or 65 are widely dispersed. A very similar picture emerges from analyzing the younger half of the original HRS cohort, born 1936-41.

The next two columns present data from the 1998 interview. Compared to respondents the same ages six years earlier, there is a small decline in the proportion of respondents who report usual retirement ages of 62 or 65 , a roughly equal-sized increase in those reporting no "usual" age for them. This pattern is somewhat reversed for the youngest cohort in 2004, who have a significant increase in the number reporting that their URA is 65 , and a corresponding reduction in the fraction saying they have no "usual" retirement age. 1

In addition to these patterns, it is worth noting two patterns that are not evident in the data. First, there is no appreciable spike at age 63. Rust and Phelan (1997) conclude that eligibility for Medicare at age 65 is an important reason for the spike in actual

\footnotetext{
${ }^{1}$ Sample weights for 2004 are not yet available, so the data for 2004 are unweighted. However, weighting made very little difference in 1992 and 1998 data. See Appendix Table 1.
} 
retirements at 65: individuals whose employers offer health insurance to workers but not to retirees (or whose retiree coverage is unattractive) postpone retirement until they can transition from employer-provided insurance to Medicare coverage. An alternative way of maintaining health insurance coverage would be to retire at $631 \frac{1}{2}$, and pay for COBRA coverage with their former employer until age 65 . However viable this option may be, it has not left significant numbers of workers thinking of 63 as a focal retirement age.

Second, the 1983 Amendments moved the age at which a worker is eligible for "full" retirement benefits gradually upward for those born after 1937. For example, the full retirement age (as it is referred to on the SSA website) for those born in 1943-54, will be 66. The birth cohorts included in Table 1 from the 2004 interview are almost completely in this group. But no more than one percent of these cohorts regard 66 as the "usual" retirement age for workers like them. While age 66 (or, for later cohorts, 67) may some day be a focal retirement age, there is not much evidence that the amendments have had such an effect on the first two cohorts whose full retirement age will be delayed to 66 .

\section{Stability of Usual Retirement Ages}

While the longitudinal nature of HRS means that particular birth cohorts may appear more than once in Table 1, the differences for a particular cohort over time reflect "attrition" (someone who stopped working between 1992 and 1998 would not appear in the 1998 data) as well as changes for a given set of individuals. However, if we focus on individuals who were working for the same employer between 1992 and 1998 (for whom, presumably, the reference group remained stable), we can measure the stability of workers' URAs.

In this restricted sample of workers who remained with the same employer over the six year period 1992-98, the mean URA remained almost unchanged (it declined by .004 years). The correlation between the 1992 and 1998 reports was .42 . (The correlation between 1992 and 1994 reports was .60. Among those working for the sample employer from 1998 to 2004, the mean usual retirement age increased by .115 
years and the correlation between 1998 and 2004 values was .41. Overall, then, beneath a remarkably stable mean URA, there a non-trivial amount of (offsetting) revisions and measurement error at the individual level. The stability of the means suggests that the URA question is not just eliciting an expectation about when the respondent will retire like a conditional life expectancy, an expected retirement date should increase over time among those who remain unretired.

\section{Usual Retirement Ages and Pensions}

In addition to differences by birth cohort and survey year, another potentially important source of variation in URAs is pension coverage. In Table 2, the initial 1992 respondents are stratified according to their (self-reported) pension status - those with no employer provided pension, those with only a DC plan (or plans), and those with a DB plan (perhaps in combination with a DC). Among those who are not covered by an employer-provided pension, nearly half say there is no "usual" retirement age for workers like them. On the other hand, those covered by DB pensions are more likely than those without pensions to report usual retirement ages of 62 or 65 , and are significantly more likely to report URAs below 60 . Because DB plans often provide accrual spikes before age 62 (Gustman and Steinmeier, 1999), this suggests that workers with DB plans designed to "get them out the door" come to see earlier retirement ages as focal. The results for those who report being covered by DC plans is more puzzling. They are significantly more likely than those without pensions to report URAs of 62 or 65 , and significantly less likely to respond that there is no usual retirement age for workers like them. But there are no accrual spikes at 62 or 65 that would link pension provisions to this greater tendency to see 62 or 65 as a usual retirement age.

\section{Usual and Expected Retirement Ages}

The wording of the HRS usual retirement age question makes it clear that it is designed to elicit the worker's perception of what others do. An alternative interpretation is that it elicits what the worker him/herself expects to do. Fortunately, the HRS also asks directly about retirement expectations. One question asks when the respondent about plans to stop working altogether: "Are you currently planning to stop working altogether 
or work fewer hours at a particular date or age, to change the kind of work you do when you reach a particular age, have you not given it much thought, or what?" Those who plan to stop working altogether are then asked "At what age do you plan to stop working altogether?" Another asks "When do you think you will retire (completely)?" For reasons that are only partially understood (differences in who is asked each question, differences between "planning” and expecting/thinking one will retire), substantially fewer respondents say they plan to stop working altogether (1695) than give a year when they plan to retire (6315). (For an analysis of these two questions and their relationship to subsequent retirement behavior, see Panis et al (2002).) We therefore focus on the second question as our measure of expected retirement date.)

The distributions of expected and usual retirement ages are quite similar - the median of both distributions is 63, and both have spikes at 62 and 65 . The expected retirement age variable has smaller peaks, and more mass at 63 and 66, but this may reflect that fact that HRS obtained an expected year of retirement, and converting this to a retirement age will, for an unknown number of respondents, lead to a retirement age that is one year too large. For example, an individual who reaches 62 in September of 2000 and who expects to retire early in 2001 will be 62 when he retires, but will have a calculated age (retirement year - year of birth $=2001-1938=63$ ). ${ }^{2}$ The expected age is somewhat more dispersed, with more responses under 60 and over 65 , as might be expected if the "usual" age is formed by averaging the experience - or the anticipated experience - of one's peers. The correlation between the expected and usual retirement ages reported at Wave I is only .40, about two thirds of the wave to wave correlation for the usual retirement measure.

If the two variables are measuring the related but distinct concepts that they are intended to capture, the usual retirement age has the advantage of being more nearly exogenous in most retirement models. A comparison of the two variables suggests that they are measuring related but distinct concepts, but more work on whether each measures what it is intended to capture is certainly warranted.

\footnotetext{
${ }^{2}$ This problem was also noted by Panis et al., who conclude that there is no way to correct it.
} 


\section{Usual and Actual Retirement Ages}

Differences in usual retirement age by birth cohort or pension status are interesting because they provide clues about what workers shapes workers' notions of the "usual" retirement age, or even whether the concept is relevant to them. But the primary reason for inquiring about URAs in the first place is the possibility that they actually predict or even influence workers' actual retirement behavior. This leads to the question: holding the worker's age and other relevant characteristics constant, are workers more likely to retire at (or around) the age they identify as the usual retirement age for workers like themselves?

To answer this question, I estimated a series of logistic regressions of the form

Probability that worker $\mathrm{i}$ retires between Wave $\mathrm{t}-1$ and Wave $\mathrm{t}=$ $\mathrm{f}$ (age at Wave $\mathrm{t}$, age at Wave $\mathrm{t}$ relative to usual retirement age, control variables)

Age at Wave $t$ is represented by a series of age dummies for single years of age (to allow for the well known spikes at 62 and 65, in addition to more general "aging" effects). Age at Wave $\mathrm{t}$ relative to usual retirement age is represented by a series of dummy variables representing years to (or past) usual retirement age. Control variables are years of schooling, annual earnings, marital status (variables for married, divorced/separated, and widowed, with never married as the reference group), health status (variables for health very good, good, fair, and poor, with health excellent as the reference group, plus a dummy variable for those who report their health limits their ability to work, and pension status (defined benefit only, defined contribution only, both DB and DC, with no pension as the reference group). Control variables are all defined at baseline (Wave 1).

Each logistic regression is estimated with the sample of workers who had not yet retired as of Wave $\mathrm{t}-1$. Thus, the first regression focuses on those who are currently working at Wave 1, and models the probability that such a worker will have retired by 
Wave 2. The second focuses on those who are still unretired at Wave 2, and models the probability that they will have retired by Wave 3 . And so on.

Unfortunately, the question which elicits usual retirement ages does not define "retirement", or elicit the respondent's definition. Thus, some respondents may be reporting the age at which workers stop working (or stop working "permanently"), while others are thinking about the age at which workers retire from their current employer. In Table 3, an individual is retired if $\mathrm{s} / \mathrm{he}$ is not employed at the interview date; in Table 4, an individual is retired if $\mathrm{s} / \mathrm{he}$ has left her/his Wave 1 employer by Wave $t$.

The first column of Table 3 shows coefficients of the URA-related variables from a logistic regression for the probability of a respondent not working at Wave II, given that $\mathrm{s} /$ he was working at Wave I. The reference (omitted) group is those whose age at the time of their Wave II interview was four or more years less than the usual retirement age they identified at Wave I. If everyone retired at the URA they had identified, then retirements would be concentrated among those whose current age equaled their URA and those who had attained their URA one year earlier (because HRS interviews respondents ever other year). In this case, the coefficients for these two variables would be large and positive, and those for the other "years to/past URA" variables would be zero. If individuals retire "near" their URA, then the other "nearby" variables should also have positive coefficients.

Perhaps the most striking finding from column 1 of Table 3 is that all of the coefficients are positive - i.e., probabilities of retirement are higher when one has less than four years to URA, or has already passed URA, than for those four or more years away from URA. While individual coefficients are not always estimated with great precision, the null hypothesis that all of the URA coefficients are zero is decisively rejected $\left(\chi^{2}(9)=85.4, P<.0001\right)$. Second, the coefficients rise as one moves from "three years to URA" to "one year past URA". Both of these results are consistent with higher rates of retirement as one approaches, and then reaches, usual retirement age. Moreover the coefficients, which measure the change in log-odds of retirement relative to the 
omitted category, are substantively important, particularly in the year or two after the worker reaches URA. Third, the coefficients are irregular for those who are two or more years beyond URA (the standard errors increase, because at Wave II respondents are age 51-61, and our sample limited to those working at Wave I, so there are relatively few individuals in this sample who are several years beyond URA. Fourth, those who report there is no "usual" retirement age for workers like them have higher retirement rates than do other workers.

The same patterns hold as one continues on to other survey years. The sample for each column consists of those who had been employed at each prior wave, so sample sizes decline (and standard errors increase) as one moves on to the later years (by Wave VI we can no longer reject the hypothesis that the URA coefficients are zero). Overall, however, the patterns found for Wave II continue to hold for later years.

An alternative definition of "retirement" is leaving one's employer - e.g., the worker who "retired from GM" but may have taken another job elsewhere. The relationship between usual retirement age and this definition of retirement is explored in Table 4. Here the dependent variable is leaving one's Wave I employer by the Wave $t$ interview, conditional on having remained with that employer up to Wave $t-1$. The most important patterns that were observed in Table 3 continue for this alternative retirement definition: those near or past URA are more likely to retire than those who are several years away, and this relationship is strongest for those who have recently reached URA. Retirement hazards are perhaps surprisingly high for those two years past URA, but the hazards decline as one gets further past URA. Those who report there is no usual retirement age for them are somewhat more likely to retire (than those whose URA is more than four years in the future). Because those who "retire" in any two year period using the earlier definition is a subset of those who retire using the Table 4 definition, sample sizes fall even faster across waves, and standard errors tend to increase, as one moves to observing retirements at later waves. Nevertheless, the hypothesis that the coefficients of the URA variables are all equal to zero can be decisively rejected until Wave VI. 
In earlier tables, we found very different patterns of usual retirement ages for those who participate in defined benefit pensions - in general, they are more likely to report that there is a usual retirement age for workers like them, and are more likely to report usual ages before 62 as well as the common focal ages (62 and 65). Given the difficulty to disentangling effects of pension incentives from other factors that determine URAs for workers with defined benefit pensions, it is worth asking whether the conclusion that URAs are related to subsequent retirement behavior continues to be valid if we exclude workers with DB pensions from the sample.

\section{Conclusions}

Previous work on the influence of "conventional" retirement ages on retirement behavior has asked whether the "spike" in retirement hazards at ages 62 and 65 persists once one takes account of various financial incentives. HRS asked respondents directly about the "usual" retirement age "for people who work with you or have the same kind of job". Empirically, direct questions have four advantages. First, they allow us to identify respondents for whom the "usual" retirement age is not very relevant (roughly one third of those age 51-61 who are currently employed). Second, they allow us to identify respondents for whom the "usual" age is not 62 or 65 (roughly one sixth of the sample). Third, among those who do report 62 or 65 , direct questions allow us to distinguish the 62's from the 65's. Fourth, we can check whether the usual retirement age has begun to respond to changes in the "full" retirement age for Social Security (there is little evidence so far that it has).

Having a usual retirement age (or an indicator that the concept is not very relevant) for each worker allows one to assess the impact of usual retirement age on subsequent retirement behavior. Across the six available waves of data after URAs were initially measured in 1992, workers of a given age are more likely to retire once they have reached their URA. Retirement hazards remain elevated for those who have past their URA, though these effects are somewhat smaller and less regular than for those closer to the usual retirement age. 
Spikes in a retirement hazard are often interpreted as increases in workers leaving at a particular age. But such spikes can also indicate that (relatively) few workers are retiring prior to the spike. We find relatively consistent evidence that those who report that there is no "usual" retirement age for workers like them tend to retire earlier than other workers - indeed, they are more likely to retire than workers who are more than three years short of their usual retirement age.

The findings in this paper suggest two lines for future research. First, it would be useful to know more about how workers' ideas of the "usual" retirement age are formed. A natural conjecture is that workers observe at what age somewhat older workers "like them" retired, and uses average behavior of this group as a starting point (or, for some, an ending point) in thinking about what might be optimal for them. Second, usual retirement ages may be particularly helpful for predicting - and, eventually, understanding - the behavior of workers who do not understand (or at least cannot accurately report in a survey context) the economic incentives that will, for other betterinformed workers, govern retirement behavior. 


\section{References}

Chan, Sewin and Stevens, Ann H. "What You Don't Know Can't Help You: Pension Knowledge and Retirement Decision Making," NBER Working Paper 10185, December 2003.

Choi, James J., David Laibson, Brigitte C. Madrian and Andrew Metrick. "Defined Contribution Pensions: Plan Rules, Participant Decisions, and the Path of Least Resistance," NBER Working Paper 8655, 2001.

Gustman, Alan L. and Steinmeier, Thomas L. "A Structural Retirement Model," Econometrica, vol. 54, no. 3, May 1986: 555-584.

Gustman, Alan L. and Steinmeier, Thomas L. Employer Provided Pension Data in the NLS Mature Women's Survey and in the Health and Retirement Study, NBER Working Paper 7174, June 1999.

Gustman, Alan L., and Steinmeier, Thomas L. "What People Don't Know about their Pensions and Social Security" in William G. Gale, John B. Shoven and Mark J. Warshawsky, editors, Public Policies and Private Pensions, Washington D.C.: Brookings Institution., 2001).

Gustman, Alan L. and Steinmeier, Thomas L. "The Social Security Early Entitlement Age in a Structural Model of Retirement and Wealth," NBER Working Paper No. 9183, September 2002.

Hurd, Michael D. "Research on the Elderly - Economic Status, Retirement, and Consumption and Saving," Journal of Economic Literature, vol. 28, no. 2, June 1990: 565-637.

Lumsdaine, Robin L., Stock, James H., and Wise, David A. "Why Are Retirement Rates So High at Age 65?" in David Wise, ed., Advances in the Economics of Aging (Chicago: University of Chicago Press, 1996): 61-82

Madrian, Brigitte, and Shea, Dennis. "The Power Of Suggestion: Inertia In 401(k) Participation and Savings Behavior," Quarterly Journal of Economics, volume 116, no. 4, November 2001: 1149-1187.

Mitchell, Olivia. "Worker Knowledge of Pension Provisions," Journal of Labor Economics, vol. 6, no. 1, January 1988: 21-39.

Panis, Constantijn; Hurd, Michael; Loughran, David; Zissimopoulos, Julie; Haider, Stephen; and StClair, Patricia. "The Effects of Changing Social Security Administrations's Early Entitlement Age and the Normal Retirement Age," RAND Report DRU-2903-SSA, June 2002. 
Peracchi, Franco and Welch, Finis. "Trends in Labor-Force Transitions of Older Men and Women," Journal of Labor Economics, vol. 12, no. 2, April 1994: 210-242.

Rust, John and Phelan, Christopher. "How Social Security and Medicare Affect

Retirement Behavior in a World of Incomplete Markets," Econometrica, vol. 64, no. 4, July 1997: 781-831. 
Table 1

Usual Retirement Age by Birth Cohort and Survey Year

\% distributions (weighted 1992 and 1998, unweighted 2004)

Survey year

Birth cohort

Usual Retirement Age:

$\leq 50$

51 to 55

56 to 60

61

62

63 to 64

65

66

67

68

69 to 70

$>70$

Defined by years of service

No usual retirement age

Total

$\mathrm{N}$ (unweighted)
1992

1931-35 1936-41 1936-41 1942-47 $1942-47 \quad 1948-53$

1931-35 1936-41 1936-41 1942-47 1942-47 $1948-53$

$$
0.2
$$

2.3

5.2

0.4

0.2

2.1

4.3

0.4

0.6

0.7

0.1

7.1

0.0

15.4

21.1

0.3

1.9

23.9

1.7

1.0

29.3

27.4

0.1

0.0

0.3

0.2

0.3

0.3

0.4

0.3

1.6

1.6

2.0

0.5

0.6

1.7

2.1

0.5

1.3

$28.7 \quad 45.4$

32.2

100.0

2591

100.0

4050
100.0

2954
5.4

7.0

0.2

18.6

0.9

25.0

0.2

0.4

0.2

1.1

0.4

2.4

37.8

100.0

2315
2.8

4.9

5.6

8.4

$\begin{array}{rr}0.1 & 0.1 \\ 15.6 & 16.9\end{array}$

$0.6 \quad 1.0$

$25.2 \quad 32.8$

$\begin{array}{ll}1.0 & 0.4\end{array}$

$0.8 \quad 0.8$

$0.7 \quad 0.6$

$2.1 \quad 2.9$

$1.0 \quad 1.0$

$1.3 \quad 1.2$

$43.2 \quad 27.6$

$100.0 \quad 100.0$

$1701 \quad 2539$

Note:

For lines representing a range of ages, the observations are clustered at the italicized age.

For example, nearly all of those in the 51-55 group reported age 55 , and nearly all of those in the 63-64 group reported age 63. 


\section{Table 2}

Usual Retirement Age by Type of Pension

$\%$ distribution, weighted Wave 1 (1992)

$\begin{array}{lrrr}\begin{array}{l}\text { Type of pension at Wave } 1 \\ \text { Usual Retirement Age }\end{array} & \text { None DC Only } & \text { Any DB } \\ \leq 50 & 0.3 & 0.2 & 0.5 \\ 51 \text { to } 55 & 1.1 & 1.5 & 6.1 \\ 56 \text { to } 60 & 3.1 & 4.9 & 10.9 \\ 61 & 0.0 & 0.1 & 0.5 \\ 62 & 15.6 & 25.0 & 29.9 \\ 63 \text { to } 64 & 0.8 & 2.4 & 2.7 \\ 65 & 25.9 & 40.1 & 31.3 \\ 66 & 0.2 & 0.1 & 0.1 \\ 67 & 0.3 & 0.4 & 0.2 \\ 68 & 0.5 & 0.3 & 0.2 \\ 69 \text { to } 70 & 2.9 & 1.6 & 0.6 \\ >70 & 0.9 & 0.5 & 0.2 \\ \text { Defined by years of service } & 0.4 & 1.2 & 3.9 \\ \text { No usual retirement age } & 47.9 & 21.7 & 12.9 \\ \text { Total } & 100.0 & 100.0 & 100.0 \\ \text { N (unweighted) } & 2950 & 1106 & 2453\end{array}$


Table 3

Usual and Actual Retirement Ages

(retirement $=$ not working at wave t|working at wave $\mathrm{t}-1$ )

$\begin{array}{lrrrrrr}\text { Retired at wave: } & \text { II (1994) } & \text { III (1996) } & \text { IV (1998) } & \text { V (2000) } & \text { VI (2002) } & \text { VII (2004) } \\ & & & & & & \\ \text { No URA } & 0.41 & 0.35 & 0.33 & 0.50 & 0.00 & -0.30 \\ & (0.10) & (0.13) & (0.16) & (0.20) & (0.26) & (0.42) \\ \text { 3 years to URA } & 0.53 & 0.25 & 0.67 & 0.20 & 0.12 & -0.81 \\ & (0.18) & (0.22) & (0.22) & (0.28) & (0.36) & (0.60) \\ \text { 2 years to URA } & 0.54 & 0.43 & 0.42 & 0.68 & 0.35 & 0.04 \\ & (0.21) & (0.21) & (0.24) & (0.26) & (0.31) & (0.53) \\ \text { 1 year to URA } & 0.72 & 0.59 & 0.28 & 0.75 & 0.19 & 0.49 \\ & (0.24) & (0.21) & (0.24) & (0.26) & (0.32) & (0.53) \\ \text { Age at survey = URA } & 1.31 & 1.00 & 0.78 & 0.79 & 0.18 & -0.26 \\ & (0.21) & (0.21) & (0.24) & (0.27) & (0.33) & (0.47) \\ \text { 1 year past URA } & 1.60 & 0.86 & 0.81 & 0.99 & 0.52 & 0.54 \\ & (0.26) & (0.25) & (0.25) & (0.27) & (0.30) & (0.48) \\ \text { 2 years past URA } & 0.76 & 0.69 & 0.56 & 0.85 & 0.40 & 0.08 \\ & (0.43) & (0.29) & (0.28) & (0.30) & (0.35) & (0.49) \\ \text { 3 years past URA } & 1.66 & 0.90 & 0.28 & 1.22 & 0.23 & -0.24 \\ & (0.46) & (0.33) & (0.36) & (0.31) & (0.37) & (0.48) \\ \text { 4 years past URA } & 0.58 & 1.59 & 0.52 & 1.19 & 0.42 & -0.23 \\ & (0.58) & (0.46) & (0.37) & (0.32) & (0.36) & (0.54) \\ \text { 5+ years past URA } & 1.14 & 0.78 & 0.27 & 0.87 & 0.55 & -0.44 \\ & (0.33) & (0.30) & (0.31) & (0.27) & (0.30) & (0.45) \\ \text { N } & 5771 & 4579 & 3557 & 2788 & 2102 & 1545\end{array}$

Notes:

Standard errors in parentheses beneath coefficients

Each logistic model includes a full set of current-age dummies, and control variables for years of schooling, annual earnings, marital status, health status, and pension coverage. See text. 
Table 4

Usual and Actual Retirement Ages

(retirement $=$ not working for Wave I (1992) employer)

$\begin{array}{lrrrrrr}\text { Retired at wave: } & \text { II (1994) } & \text { III (1996) } & \text { IV (1998) } & \text { V (2000) } & \text { VI (2002) } & \text { VII (2004) } \\ \text { No URA } & & & & & & \\ & 0.24 & 0.21 & 0.38 & 0.58 & 0.04 & -0.57 \\ \text { 3 years to URA } & (0.07) & (0.12) & (0.16) & (0.23) & (0.33) & (0.58) \\ & 0.47 & 0.06 & 0.45 & 0.27 & 0.10 & -1.26 \\ \text { 2 years to URA } & (0.15) & (0.21) & (0.22) & (0.31) & (0.46) & (0.79) \\ & 0.02 & 0.46 & 0.54 & 0.58 & 0.12 & 0.05 \\ \text { 1 year to URA } & (0.17) & (0.20) & (0.25) & (0.28) & (0.38) & (0.68) \\ & 0.61 & 0.69 & 0.55 & 0.73 & 0.53 & -0.73 \\ \text { Age at survey = URA } & (0.21) & (0.20) & (0.25) & (0.30) & (0.36) & (0.73) \\ & 0.99 & 0.81 & 0.71 & 0.57 & 0.09 & -0.57 \\ \text { 1 year past URA } & (0.20) & (0.21) & (0.25) & (0.32) & (0.41) & (0.62) \\ & 1.07 & 0.91 & 1.21 & 1.12 & 0.42 & 0.32 \\ \text { 2 years past URA } & (0.25) & (0.26) & (0.27) & (0.31) & (0.38) & (0.64) \\ & 0.92 & 0.91 & 0.76 & 1.10 & 0.83 & -0.45 \\ \text { 3 years past URA } & (0.37) & (0.28) & (0.30) & (0.36) & (0.43) & (0.66) \\ & 1.20 & 0.91 & 1.04 & 0.51 & -0.07 & -0.55 \\ \text { 4 years past URA } & (0.43) & (0.36) & (0.37) & (0.40) & (0.48) & (0.65) \\ & 0.03 & 1.25 & 0.89 & 1.31 & -0.56 & -0.78 \\ \text { 5+ years past URA } & (0.56) & (0.57) & (0.40) & (0.40) & (0.51) & (0.76) \\ & 1.24 & 0.81 & 0.18 & 0.50 & 0.73 & -0.81 \\ \text { N } & (0.32) & (0.31) & (0.36) & (0.34) & (0.38) & (0.62) \\ & 5771 & 3296 & 2269 & 1559 & 1046 & 659\end{array}$

Notes:

Standard errors in parentheses beneath coefficients

Each logistic model includes a full set of current-age dummies, and control variables for years of schooling, annual earnings, marital status, health status, and pension coverage. See text. 
Appendix Table 1

Usual Retirement Age by Birth Cohort and Survey Year

$\%$ distributions (unweighted and weighted, 1992 and 1998)

Weighting
Survey year
Birth cohort
$\leq 50$
51 to 55
56 to 60
61
62
63 to 64
65
66
67
68
69 to 70
$>70$
Defined by years of service
No usual retirement age
Total
N (unweighted)

\begin{tabular}{|c|c|c|c|c|c|c|c|}
\hline \multicolumn{4}{|c|}{ unweighted } & \multicolumn{4}{|c|}{ weighted } \\
\hline \multicolumn{2}{|c|}{1992} & \multicolumn{2}{|c|}{1998} & \multicolumn{2}{|c|}{1992} & \multicolumn{2}{|c|}{1998} \\
\hline 1931-35 & $1936-41$ & $1936-41$ & $1942-47$ & $1931-35$ & $1936-41$ & $1936-41$ & $1942-47$ \\
\hline 0.3 & 0.4 & 0.2 & 0.3 & 0.2 & 0.4 & 0.2 & 0.4 \\
\hline 2.4 & 3.6 & 2.2 & 5.5 & 2.3 & 3.5 & 2.1 & 5.4 \\
\hline 4.9 & 6.6 & 4.2 & 7.2 & 5.2 & 7.1 & 4.3 & 7.0 \\
\hline 0.1 & 0.3 & 0.0 & 0.2 & 0.1 & 0.3 & 0.0 & 0.2 \\
\hline 21.8 & 24.0 & 16.2 & 18.3 & 21.1 & 23.9 & 15.4 & 18.6 \\
\hline 1.7 & 1.7 & 1.0 & 0.8 & 1.9 & 1.7 & 1.0 & 0.9 \\
\hline 31.6 & 29.2 & 27.2 & 24.1 & 31.9 & 29.3 & 27.4 & 25.0 \\
\hline 0.2 & 0.0 & 0.1 & 0.2 & 0.3 & 0.0 & 0.1 & 0.2 \\
\hline 0.2 & 0.3 & 0.3 & 0.4 & 0.2 & 0.3 & 0.3 & 0.4 \\
\hline 0.4 & 0.3 & 0.2 & 0.1 & 0.5 & 0.4 & 0.3 & 0.2 \\
\hline 1.9 & 1.7 & 1.5 & 1.0 & 2.0 & 1.6 & 1.6 & 1.1 \\
\hline 0.5 & 0.6 & 0.5 & 0.4 & 0.5 & 0.6 & 0.5 & 0.4 \\
\hline 2.0 & 2.5 & 1.5 & 2.5 & 1.7 & 2.1 & 1.3 & 2.4 \\
\hline 32.2 & 28.8 & 44.9 & 38.9 & 32.2 & 28.7 & 45.4 & 37.8 \\
\hline 100.0 & 100.0 & 100.0 & 100.0 & 100.0 & 100.0 & 100.0 & 100.0 \\
\hline 2591 & 4050 & 2954 & 2315 & 2591 & 4050 & 2954 & 2315 \\
\hline
\end{tabular}




$$
\begin{gathered}
\text { Appendix Table } 2 \\
\text { Usual and Actual Retirement Ages } \\
\text { (retirement }=\text { not working for Wave I (1992) employer) } \\
\text { sample }=\text { those with no pension or DC only }
\end{gathered}
$$

$\begin{array}{lrrrrrr}\text { Retired at wave: } & \text { II (1994) } & \text { III (1996) } & \text { IV (1998) } & \text { V (2000) } & \text { VI (2002) } & \text { VII (2004) } \\ & & & & & & \\ \text { No URA } & 0.23 & 0.16 & 0.48 & 0.56 & -0.12 & 0.56 \\ & (0.08) & (0.13) & (0.19) & (0.25) & (0.32) & (0.41) \\ \text { 3 years to URA } & 0.30 & -0.27 & 0.18 & 0.47 & 0.49 & 0.18 \\ & (0.20) & (0.33) & (0.35) & (0.42) & (0.52) & (0.62) \\ \text { 2 years to URA } & 0.04 & 0.31 & 1.05 & 0.43 & 0.00 & 1.86 \\ & (0.23) & (0.29) & (0.33) & (0.39) & (0.46) & (0.67) \\ \text { 1 year to URA } & 0.77 & 0.62 & 0.56 & 0.68 & 0.95 & -0.41 \\ & (0.31) & (0.30) & (0.38) & (0.44) & (0.49) & (0.82) \\ \text { Age at survey = URA } & 0.74 & 1.02 & 0.91 & -0.04 & -0.12 & -0.09 \\ & (0.30) & (0.34) & (0.36) & (0.45) & (0.50) & (0.59) \\ \text { 1 year past URA } & 0.18 & 0.52 & 1.36 & 0.85 & -0.57 & 1.88 \\ & (0.41) & (0.44) & (0.40) & (0.42) & (0.49) & (0.65) \\ \text { 2 years past URA } & -0.74 & 0.29 & 0.02 & 1.03 & 1.01 & 0.82 \\ & (0.67) & (0.54) & (0.54) & (0.52) & (0.49) & (0.61) \\ \text { 3 years past URA } & 1.58 & 1.02 & 1.82 & -0.45 & -0.04 & -0.34 \\ & (0.75) & (0.58) & (0.64) & (0.61) & (0.61) & (0.71) \\ \text { 4 years past URA } & -0.20 & 0.46 & 0.79 & 1.13 & -0.37 & -0.33 \\ & (0.95) & (1.26) & (0.68) & (0.61) & (0.59) & (0.84) \\ \text { 5+ years past URA } & 1.10 & 0.06 & 0.63 & 0.04 & 0.59 & 0.40 \\ & (0.62) & (0.69) & (0.60) & (0.56) & (0.47) & (0.52) \\ \text { N } & 4088 & 3285 & 2623 & 2137 & 1679 & 1350\end{array}$

Notes:

Standard errors in parentheses beneath coefficients

Each logistic model includes a full set of current-age dummies, and control variables for years of schooling, annual earnings, marital status, health status, and pension coverage. See text. 


$$
\begin{gathered}
\text { Appendix Table } 3 \\
\text { Usual and Actual Retirement Ages } \\
\text { (retirement }=\text { not working for Wave I (1992) employer) } \\
\text { sample }=\text { those with no pension or DC only }
\end{gathered}
$$

$\begin{array}{lrrrrrr}\text { Retired at wave: } & \text { II (1994) } & \text { III (1996) } & \text { IV (1998) } & \text { V (2000) } & \text { VI (2002) } & \text { VII (2004) } \\ \text { No URA } & & & & & & \\ & 0.33 & 0.38 & 0.42 & 0.35 & -0.02 & 0.29 \\ \text { 3 years to URA } & (0.11) & (0.14) & (0.18) & (0.20) & (0.24) & (0.30) \\ & -0.05 & 0.18 & 0.35 & 0.34 & 0.55 & -0.14 \\ \text { 2 years to URA } & (0.27) & (0.32) & (0.33) & (0.35) & (0.39) & (0.48) \\ & 0.82 & 0.37 & 0.86 & 0.45 & 0.35 & 0.23 \\ \text { 1 year to URA } & (0.27) & (0.28) & (0.32) & (0.32) & (0.35) & (0.51) \\ & 0.84 & 0.48 & 0.32 & 0.72 & 0.30 & 0.68 \\ \text { Age at survey = URA } & (0.36) & (0.29) & (0.34) & (0.33) & (0.39) & (0.48) \\ & 1.11 & 1.22 & 0.83 & 0.46 & 0.19 & 0.09 \\ \text { 1 year past URA } & (0.30) & (0.30) & (0.32) & (0.34) & (0.39) & (0.43) \\ & 1.16 & 0.73 & 0.71 & 0.55 & 0.25 & 1.18 \\ \text { 2 years past URA } & (0.43) & (0.38) & (0.35) & (0.35) & (0.35) & (0.45) \\ & -12.33 & 0.25 & 0.16 & 0.76 & 0.40 & 0.79 \\ \text { 3 years past URA } & (318.40) & (0.48) & (0.44) & (0.39) & (0.39) & (0.44) \\ & 1.43 & 0.83 & 0.50 & 0.65 & 0.29 & -0.14 \\ \text { 4 years past URA } & (0.73) & (0.49) & (0.53) & (0.39) & (0.45) & (0.49) \\ & 0.42 & 2.31 & -0.59 & 0.75 & 0.62 & 0.29 \\ \text { 5+ years past URA } & (1.13) & (0.79) & (0.80) & (0.47) & (0.41) & (0.52) \\ & -0.02 & 0.56 & 0.04 & 0.84 & 0.70 & 0.61 \\ \text { N } & (0.68) & (0.50) & (0.54) & (0.37) & (0.34) & (0.35) \\ & 4088 & 1981 & 1388 & 990 & 704 & 483\end{array}$

Notes:

Standard errors in parentheses beneath coefficients

Each logistic model includes a full set of current-age dummies, and control variables for years of schooling, annual earnings, marital status, health status, and pension coverage. See text. 